\title{
RESEARCH PAPER \\ Resistance inducers and biochemical mechanisms in the control of anthracnose in cowpea
}

\author{
Jéssica Morais da Silva ${ }^{1}$, Maria do Bom Conselho Lacerda Medeiros ${ }^{1}$, João \\ Tiago Correia Oliveira ${ }^{1}$, Erika Valente de Medeiros $^{1}$, Cristina Maria de \\ Souza-Motta ${ }^{2}$, and Keila Aparecida Moreira ${ }^{1}$ \\ ${ }^{1}$ Rural Federal University of Pernambuco, Academic Unit of Garanhuns. Avenida Bom Pastor, s/n - Boa \\ Vista, Garanhuns, Pernambuco, Brazil. \\ ${ }^{2}$ Federal University of Pernambuco, Department of Mycology. Av. Dom Manoel de Medeiros, s/n, Recife, \\ Pernambuco, Brazil.
}

\begin{abstract}
J. M. Silva, M. B. C. L. Medeiros, J. T. C. Oliveira, E. V. Medeiros, C. M. Souza-Motta, and K. A. Moreira. 2018. Resistance inducers and biochemical mechanisms in the control anthracnosis on cowpea. Cien. Inv. Agr. 45(3): 290-300. Different responses are observed in plants after infection by pathogens. The usage of systemic inducers, whether biotic or abiotic, has the function to increase the enzymatic production of the plant defense system. In that sense, our present research aims to evaluate the disease severity of anthracnose in the cowpea cultivar "sempre-verde" infected with Colletotrichum lindemuthianum URM 5771 and subjected to both biotic and abiotic resistance inducers, as well as evaluate the enzymatic activity of plant defense. The experiment was performed in a greenhouse with a completely randomized splitplot design with six treatments: four abiotic plant resistance inducers, acibenzolar-S-methyl, $\beta$-aminobutyric acid, chitosan, and salicylic acid; one biotic inducer, the filamentous fungi Trichoderma aureoviride URM 5158; and a control with only water. The plant leaves were sampled at four time points, $4,8,12$ and 20 days after inoculation with the plant pathogen, to measure the enzymatic activity of $\beta$-1,3-glucanase, catalase, peroxidase, polyphenoloxidase, and protease. The abiotic inducers acibenzolar-S-methyl, $\beta$-aminobutyric acid, and chitosan and the biotic inducer presented the highest potential in reducing the anthracnose caused by $C$. lindemuthianum URM 5771 in cowpea plants by showing the lowest values of injury severity over time. The disease progression showed a proportionate shift in enzymatic activity in that the inducers salicylic acid and T. aureoviride URM 5158 promoted the highest enzymatic activity when compared to the other inducers. High correlations between the enzymatic activity of peroxidase and polyphenoloxidase and anthracnose severity were observed in cowpea plants. The use of abiotic and biotic resistance inducers presents high potential for anthracnose control in cowpea plants; however, more studies should be carried out covering different environments, plant cultivars and climatic conditions.
\end{abstract}

Keywords: Abiotic inducers, bean disease, biotic inducers, Vigna unguiculata (L.) Walp.

Received Mar 22, 2018. Accepted Sep 24, 2018.

Corresponding author: moreirakeila@hotmail.com1 


\section{Introduction}

Cowpea (Vigna unguiculata (L.) Walp.) is one of the major subsistence crops in sub-Saharan Africa and in northern and northeastern Brazil (Santos et al., 2017). Approximately 14.5 million hectares are cultivated worldwide, with an estimated production of 12.5 million tons of grain (FAO, 2013).

In Brazil, approximately 1,300 thousand haw as planted with cowpea in 2016/2017, which produced $453 \mathrm{~kg} \mathrm{ha}^{-1}$, well below the estimated productive potential of 5,000 to $6,000 \mathrm{~kg} \mathrm{ha}^{-1}$. Despite its low productivity, the cowpea is one of the main sources of energy and protein consumed by local communities, generating jobs and income for both rural and urban populations (CONAB, 2017). Cowpea crops have a low productivity mainly due to the low availability of nutrients, the attack of plant pathogens, and reduced technological support, as this crop is commonly associated with subsistence agriculture (Mohanapriya et al., 2017).

Among the plant diseases that compromise cowpea productivity, anthracnose, caused by fungi from the genus Colletotrichum, corresponds to one of the main plant diseases and may even lead to total crop loss (Pradhan et al., 2017). Usually, chemical control is used as the mitigation strategy for this pathogen, however, recently, there has been an increased interest in new techniques that minimize environmental impact. Among those techniques, one of the most promising is the induction of plant systemic resistance.

Several chemical products, so-called abiotic inducers, have demonstrated the capacity to induce the expression of systemic acquired resistance such as acibenzolar-S-methyl and others (Ramírez et al., 2014). However, the application of nonpathogenic microbes might also work as biotic inducers of plant systemic resistance (Silva et al., 2016a).

Among the microorganisms used in the biological control of plant diseases, Trichoderma spp. has emerged as one of the most promising and studied biocontrol agents acting against a wide variety of plant pathogens. The mode of action of Trichoderma spp. is associated with nutrient competition, hyperparasitism, and antibiosis via biochemical agents with an increase in enzymes that degrade the cell wall (Silva et al., 2017).

Plants respond to a series of mechanisms when infected by pathogens. Thus, the usage of abiotic and biotic inducers of plant systemic resistance increases the production of several plant enzymes (Singh et al., 2011). Few studies have been conducted on the abiotic and biotic resistance inducers in cowpea. In that sense, our present research aimed to evaluate the disease severity and enzymatic activity in the cowpea cultivar "sempre-verde" infected with Colletotrichum lindemuthianum URM 5771 when subjected to both abiotic and biotic inducers of plant resistance.

\section{Material and Methods}

The experiment was performed in a greenhouse at the Federal Rural University of Pernambuco - Academic Unit of Garanhuns, Brazil. The climate classification for the municipality is Csa, tropical mesothermal, according to the Köppen-Geiger (1928) classification. The area has anannual mean temperature of $20^{\circ} \mathrm{C}$ and annual average rainfall of $1,300 \mathrm{~mm}$.

\section{Cultivation of cowpea plants and application of systemic resistance inducers}

The experiment was a completely randomized split-plot design with six treatments: four abiotic resistance inducers [acibenzolar-S-methyl $(\mathrm{BION} 囚), \beta$-aminobutyric acid (BABA), chitosan, and salicylic acid], one biotic resistance inducer (the filamentous fungi Trichoderma aureoviride URM 5158), and a control of sterilized water. Our sampling scheme consisted of four time points $(4,8,12$, and 20 days after the inoculation of $C$. lindemuthianum URM 5771). Every treatment had four replicates. 
The filamentous fungi T. aureoviride URM 5158 and $C$. lindemuthianum URM 5771, causing anthracnose in cowpea plants, were obtained from the URM Mycobank, the Department of Mycology in the Federal University of Pernambuco, Brazil.

The plants were cultivated in $4 \mathrm{~L}$ pots containing sterilized soil and kept in a green house with a relative humidity of $70 \%$. The ambient temperature was monitored daily, with a mean of $26^{\circ} \mathrm{C}\left( \pm 2.3^{\circ} \mathrm{C}\right)$. To control pot humidity, we determined the water holding capacity via direct and daily weighing of each pot followed by the replacement of water to recover the losses by evapotranspiration when necessary (Leal et al., 2008).

Four commercial seeds of the cowpea cultivar "sempre-verde," with a germination rate of $86.0 \%$, were planted per pot, and five days after emergence, thinning occurred, with one seedling being left per pot. Thirty days after emergence, we sprayed each abiotic and biotic resistance inducer until the leaves became completely wet. To determine the dose of each abiotic resistance inducer, we used the manufacturer's recommendations as follows: BION $0.05 \mathrm{mg} \mathrm{L}^{-1}$, BABA $10.0 \mathrm{mg} \mathrm{mL}^{-1}$, chitosan $2.0 \mathrm{mg} \mathrm{mL}^{-1}$, and salicylic acid $10.0 \mathrm{mg} \mathrm{mL}^{-1}$. For the biotic inducer, we applied a concentration of $10^{6}$ conidia $\mathrm{mL}^{-1}$.

Thirty-two days after emergence, plants were inoculated with $C$. lindemuthianum URM 5771 at a concentration of $10^{6}$ conidia per $\mathrm{mL}^{-1}$. Then, the plants were covered with plastic bags for three days to favor disease development. The evaluation of disease severity and leaf sampling to determine the enzymatic activity was performed 36, 41, 45, and 52 days after emergence.

Soil was obtained from the 0.0-0.2 m layer in an area of native forest in the municipality of São João, Pernambuco, Brazil and was classified as a typical regosol. The chemical composition was $\mathrm{pH} 4.5 ; 16.6 \mathrm{mg} \mathrm{kg}^{-1}$ of P; $0.8 \mathrm{cmol}_{\mathrm{c}} \mathrm{dm}^{-3}$ of $\mathrm{Ca}^{2+} ; 0.8 \mathrm{cmol}_{\mathrm{c}} \mathrm{dm}^{-3}$ of $\mathrm{Mg}^{2+} ; 0.15 \mathrm{cmol}_{\mathrm{c}} \mathrm{kg}^{-1}$ of
$\mathrm{Al}^{3+} ; 1.8 \mathrm{cmol}_{\mathrm{c}} \mathrm{dm}^{-3}$ of $\mathrm{H}+\mathrm{Al}$. The soil physical analysis characterized the soil as sandy with $880 \mathrm{~g} \mathrm{~kg}^{-1}$ of sand, $40 \mathrm{~g} \mathrm{~kg}^{-1}$ of clay, and $80 \mathrm{~g}$ $\mathrm{kg}^{-1}$ of silt.

Before the experimental setup, the soil was air-dried, sieved at $2 \mathrm{~mm}$, homogenized, and sterilized in an autoclave for $2 \mathrm{~h}$ at $121^{\circ} \mathrm{C}$. Then, the samples were dried and rested for two weeks to eliminate fungi propagules and stabilize the heavy metal content according to the methods adapted from Silva et al. (2016b).

\section{Evaluation of disease severity of anthracnose in cowpea plants}

We used the scale adopted by Rava et al. (1993), which varies from 1 to 9: 1 - absence of symptoms; 2 - up to $1 \%$ of leaf veins with necrotic spots, visible only in the inferior part of the leaf; 3 - higher frequency of the symptoms described in scale 2 , representing $3 \%$ of infected leaf veins; 4 - up to $1 \%$ of leaf veins with necrotic spots on both sides of the leaves; 5 - same symptoms presented as in 4 but reaching up to $3 \%$ of leaf veins; 6 - necrotic spots on both sides of the leaves with visible lesions on the midrib, petiole, and branches; 7 - necrotic spots in the majority of leaf veins with a great part of the adjacent mesophyll tissue rupturing and the abundant presence of lesions on the midrib, petiole, and branches; 8 - necrotic spots in almost the totality of plant veins causing rupture, defoliation, and plant growth reduction as well as much more abundant lesions in the midrib, petiole and branches; and 9 - dead plant.

Extraction and estimation of antioxidant enzymes in cowpea plants

In each treatment, five leaves from each plant were homogenized at $4{ }^{\circ} \mathrm{C}$ to evaluate the enzymatic activity. The samples were ground in liquid $\mathrm{N}_{2}$ and $4 \mathrm{~mL}$ of $50 \mathrm{mM}$ potassium phosphate $(\mathrm{pH}$ 
7.0). To avoid oxidative effects, we added $0.05 \mathrm{~g}$ of polyvinylpyrrolidone (PVP). The solution was centrifuged under refrigeration at $4{ }^{\circ} \mathrm{C}$ and 10000 $\mathrm{x} g$ for $10 \mathrm{~min}$. The supernatant was stored in a microtube at $-20{ }^{\circ} \mathrm{C}$ (Andrade et al., 2013) until further analysis.

The evaluation of the $\beta$-1,3-glucanase (GLU, E.C. 3.2.1.6) and catalase activities (CAT, E.C. 1.11.1.6) was determined according to the procedures described in Lever (1972) and Havir and Mchale (1987), respectively. The peroxidase activity (POX, E.C. 1.11.1) was evaluated following the method described by Urbanek et al. (1991), which used guaiacol and $\mathrm{H}_{2} \mathrm{O}_{2}$ as substrates. The polyphenoloxidase activity (PPO, E.C. 1.10.3.1) was evaluated via the oxidation of pyrogallol following the procedures described in Kar and Mishra (1976), and the protease activity (PRO, E.C. 3.4.21.4) was assessed according to the methods proposed by Alencar et al. (2003). The enzymatic activities are expressed in $\mathrm{U} \mathrm{min}^{-1} \mathrm{mg}^{-1}$.

\section{Statistical analysis}

The data on disease severity and enzymatic activity were analyzed via orthogonal contrast using the t-test $(p \leq 0.05$ and 0.01$)$. Then, the data were evaluated with analysis of variance in a split-plot design via an F-test followed by a post hoc test of Scott-Knott ( $p \leq 0.05)$ using Sisvar software. The enzymatic activity data were $\log 10$ transformed and then used to construct a dispersion chart by principal component analysis based on the Euclidian distance matrix using the software PAST. A regression analysis was performed to verify the relationship between the disease severity and enzymatic activity according to treatment.

\section{Results and Discussion}

The biotic and abiotic inducers of systemic resistance reduced the severity of anthracnose when compared to the control. There was no statistical difference between the abiotic and biotic resistance inducers (Table 1).

The analysis of $C$. lindemuthianum URM 5771 infection along our time points showed that days 4 and 8 did not present significant differences among treatments. After this time, the disease increased in the control treatment. The chitosan and $T$. aureoviride URM 5158 treatments promoted strong disease resistance the disease severity level did not change between time points (Table 2). We emphasize that all resistance inducers prevented the development of anthracnose in cowpea plants. In the control treatment, the disease severity according to the scale described by Rava et al. (1993) reached a level in which up to $1 \%$ of leaf veins presented necrotic spots visible on both sides of the leaves, characterizing the intermediate phase of disease aggravation.

When subjected to abiotic or biotic stress, the plants rapidly produced reactive oxygen species such as singlet oxygen $\left({ }^{1} \mathrm{O}_{2}\right)$, anion superoxide $\left(\mathrm{O}_{2}^{-}\right)$, and, especially, hydrogen peroxide $\left(\mathrm{H}_{2} \mathrm{O}_{2}\right)$ and the hydroxyl group $\left(\mathrm{OH}^{-}\right)$. The accumulation of these substances in plant cells has a toxic effect on both plants and stressor agents (Nascimento and Barrigossi, 2014). To protect against the side effects of these reactive oxygen species, plant cells initiate a defense system with the production of enzymes and other molecules, such as carotenoids, ascorbic acid, vitamin E, flavonoids, proline, and glutathione, together with the induction of plant defense genes and the polymerization of proteins that compose the cell wall (Davar et al., 2013).

Many enzymes, such as catalase, polyphenoloxidase, and peroxidase, among others, demonstrate the capacity to decompose reactive oxygen species (Mittler, 2002). Changes in this enzymatic system of antioxidants are one of the first plant responses to pathogenic invasion, as revealed by Silva et al. (2017) when evaluating the resistance induced by Trichoderma on manioc plants subjected to 
Table 1. Comparison between the group means of orthogonal constants and the anthracnose disease severity and enzymatic activities in leaves of the cowpea cultivar "sempre-verde" (Vigna unguiculata (L.) Walp.) subjected to the abiotic resistance inducers (AI) acibenzolar-S-methyl, $\beta$-aminobutyric acid, chitosan, and salicylic acid and the biotic inducer Trichoderma aureoviride URM 5158 (BI) after infection with Colletotrichum lindemuthianum URM 5771.

\begin{tabular}{|c|c|c|c|c|c|c|}
\hline \multirow[b]{2}{*}{ Average } & \multirow{2}{*}{$\begin{array}{l}\text { Disease } \\
\text { severity }\end{array}$} & \multicolumn{5}{|c|}{ Enzymatic $\left(\mathrm{U} \mathrm{min}^{-1} \mathrm{mg}^{-1}\right)$} \\
\hline & & $\begin{array}{c}\beta-1,3- \\
\text { Glucanase }\end{array}$ & Catalase & Peroxidase & Polyphenoloxidase & Protease \\
\hline Inducers & 1.95 & 2.52 & 43.48 & 0.15 & 0.47 & 0.62 \\
\hline AI & 1.94 & 2.72 & 36.38 & 0.12 & 0.38 & 0.63 \\
\hline BI & 2.00 & 2.32 & 50.58 & 0.19 & 0.55 & 0.61 \\
\hline Control & 2.94 & 2.90 & 34.12 & 0.35 & 0.33 & 0.69 \\
\hline General & 2.11 & 2.68 & 38.37 & 0.17 & 0.40 & 0.64 \\
\hline \multicolumn{7}{|c|}{ Inducers $v s$. Control } \\
\hline Test t & $-4.38 *$ & $-8.88 *$ & $0.78 *$ & $-3.34 * *$ & $1.36^{*}$ & $-1.30 *$ \\
\hline CV $(\%)$ & 19.25 & 29.41 & 29.75 & 32.75 & 24.57 & 29.36 \\
\hline \multicolumn{7}{|c|}{ IA vs. Control } \\
\hline Test t & $-4.12 *$ & $-0.60^{\text {ns }}$ & $0.34^{\mathrm{ns}}$ & $-3.49 * *$ & $0.88 *$ & $-1.15^{*}$ \\
\hline CV $(\%)$ & 20.47 & 26.72 & 27.45 & 22.75 & 21.29 & 26.44 \\
\hline \multicolumn{7}{|c|}{ IB vs. Control } \\
\hline Test $\mathrm{t}$ & $-3.22 * *$ & $-1.53^{*}$ & $1.96^{* *}$ & $-1.99 * *$ & $2.70^{* *}$ & $-1.38 *$ \\
\hline CV $(\%)$ & 20.17 & 23.45 & 28.67 & 20.75 & 19.81 & 23.36 \\
\hline \multicolumn{7}{|l|}{ IA $v s$. IB } \\
\hline Test t & $-2.71^{\mathrm{ns}}$ & $1.35^{*}$ & $-2.14 * *$ & $-2.60 * *$ & $-1.06^{*}$ & $0.60^{\mathrm{ns}}$ \\
\hline CV (\%) & 18.20 & 18.52 & 27.11 & 31.52 & 24.84 & 26.92 \\
\hline
\end{tabular}

ns-Not significant; * and **-Significant at $5 \%$ and $1 \%$ probability by t-test; CV-Coefficient of variation.

Table 2. Evaluation of disease severity of Colletotrichum lindemuthianum URM 5771 in leaves of the cowpea cultivar "sempre-verde" (Vigna unguiculata (L.) Walp.) subjected to different abiotic resistance inducers and to the biotic inducer Trichoderma aureoviride URM 5158.

\begin{tabular}{lccccc}
\hline \multirow{2}{*}{ Treatments } & \multicolumn{4}{c}{ Days after infection with C. lindemuthianum URM 5771 } & \multirow{2}{*}{$\begin{array}{c}\text { CV } \\
\text { (\%) }\end{array}$} \\
\cline { 2 - 5 } 4th Day & 8th day & 12th Day & 20th day & \\
\hline BION ${ }^{1}$ & $1.25 \mathrm{Ab}$ & $1.50 \mathrm{Ab}$ & $1.75 \mathrm{Bb}$ & $2.75 \mathrm{Ba}$ & \\
BABA & $1.25 \mathrm{Ab}$ & $2.00 \mathrm{Aa}$ & $2.50 \mathrm{Ba}$ & $2.50 \mathrm{Ba}$ & \\
Chitosan & $1.50 \mathrm{Aa}$ & $2.00 \mathrm{Aa}$ & $2.50 \mathrm{Ba}$ & $2.50 \mathrm{Ba}$ & 19.50 \\
Salicylic acid & $1.00 \mathrm{Ab}$ & $1.50 \mathrm{Ab}$ & $2.00 \mathrm{Ba}$ & $2.50 \mathrm{Ba}$ & \\
T. aureoviride & $1.50 \mathrm{Aa}$ & $2.00 \mathrm{Aa}$ & $2.00 \mathrm{Ba}$ & $2.50 \mathrm{Ba}$ & \\
Control & $1.50 \mathrm{Ac}$ & $2.75 \mathrm{Ab}$ & $3.50 \mathrm{Aa}$ & $4.00 \mathrm{Aa}$ & \\
CV $(\%)$ & 18.50 & & & & \\
\hline
\end{tabular}

BION®: Acibenzolar-S-methyl; BABA: Amino-butyric acid; Disease severity assessed based on the grading scale of Rava et al. (1993); CV: Coefficient of variation; Means followed by the same capital letter in the column and lowercase letter in the row do not differ from each other by the Scott-Knott test at a probability of $5 \%$.

the presence of Scytalidium lignicola, the causal agent of black root rot.

In our study, the inducers of resistance increased the enzymatic activity of catalase and polyphenol oxidase, but the treatment with abiotic inducers did not differ from the control treatment (Table 1). Among the resistance inducers, the fungi T. aureoviride URM 5158 induced the highest activity of catalase, peroxidase, and polyphenoloxidase when compared to the other abiotic inducers. This result highlights the potential application of this fungi as a biological control agent, as suggested by the evaluation of disease severity (Table 1 and 2). We emphasize that plants subjected to stress even without the 
addition of external agents capable of inducing plant resistance may present high values of antioxidant enzyme activity, which contribute to reducing the influence of the phytopathogen.

As the disease progressed on plant leaves, a change was observed in the enzymatic activity without a clear distinction or grouping among treatments (Figure 1). This result suggested the presence of a heterogeneous response in plant enzymatic activity according to the systemic resistance induced by each abiotic agent. However, when we compared the treatments at different time points after infection with $C$. lindemuthianum URM 5771, we observed that over time, regardless of the evaluated enzyme, the control treatment reached or surpassed the levels of enzymatic activity induced by our treatments (Table 3).

The enzyme $\beta$-1,3-glucanase showed the highest activity on days 4,12 , and 20 after infection with
C. lindemuthianum URM 5771, and a similar result was also observed for the abiotic inducers chitosan and salicylic acid (Table 3). Both $\beta-1,3$-glucanase and chitinase degrade glucan and chitin, the main components of the fungi cell wall and the exoskeleton of insects, thus protecting the plant against infections (Bol et al., 1990).

For the catalase enzyme, the highest activity peaked 12 days after the infection with the pathogen for all of the resistance inducers, except for salicylic acid. Among the resistance inducers, we highlight BABA and T. aureoviride URM 5158. For peroxidase and polyphenoloxidase, the activity peaked after 4 days of infection with the plant pathogen. The resistance inducers BION and chitosan promoted a high activity of peroxidase and polyphenoloxidase, respectively, at all the evaluated time points. However, the highest activities occurred in the treatments with salicylic acid and T. aureoviride URM 5158 (Table 3).
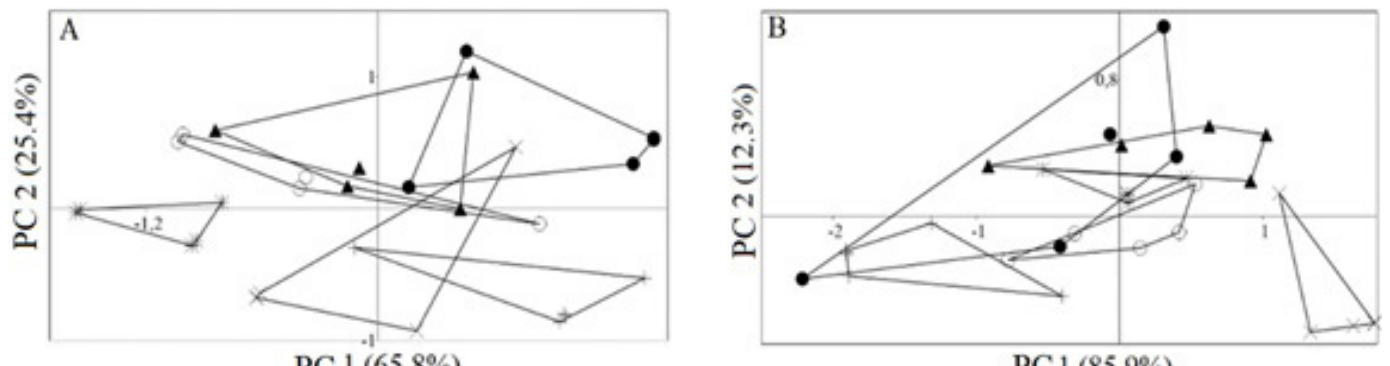

PC $1(65.8 \%)$

PC1 $(85.9 \%)$
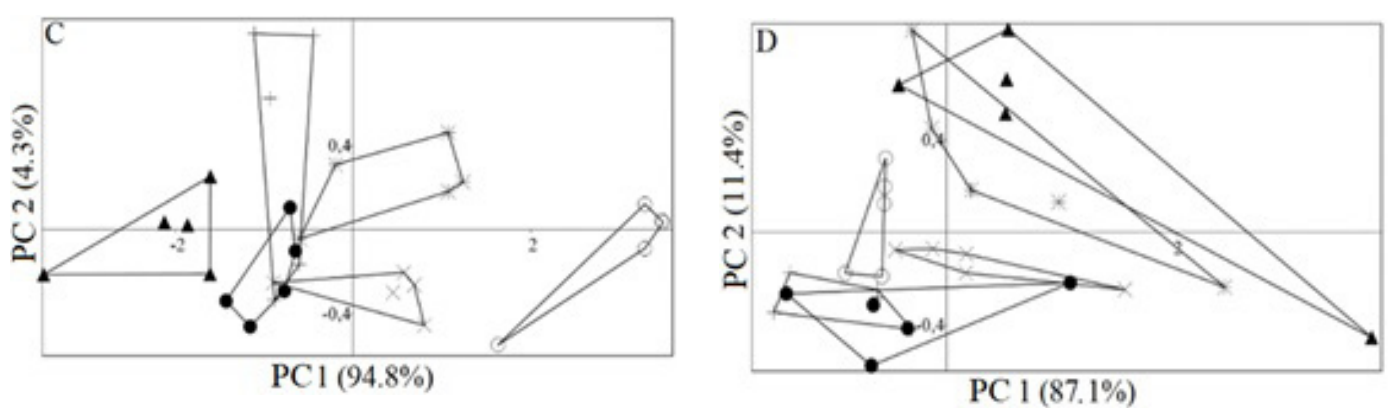

Figure 1. Principal component (PC) analysis of the enzymatic activity of $\beta$-1,3-glucanase, catalase, peroxidase, polyphenol oxidase, and protease $\left(\mathrm{U} \mathrm{min}^{-1} \mathrm{mg}^{-1}\right.$ ) in leaves of the cowpea cultivar "sempre-verde" (Vigna unguiculata (L.) Walp.) subjected to abiotic or biotic resistance inducers and infected with Colletotrichum lindemuthianum URM 5771. Days after infection, A: 4 days; B: 8 days; C: 12 days; and D: 20 days. Treatments: $(\times)$ Acibenzolar-S-methyl (BION®); (+)

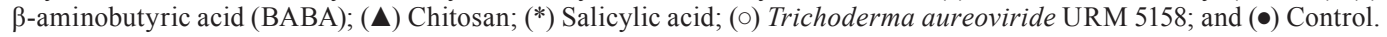


Table 3. Enzymatic activity $\left(\mathrm{U} \mathrm{min}^{-1} \mathrm{mg}^{-1}\right)$ of leaves of the cowpea cultivar "sempre-verde" (Vigna unguiculata (L.) Walp.) subjected to abiotic and biotic (Trichoderma aureoviride URM 5158) resistance inducers and infected with Colletotrichum lindemuthianum URM 5771.

\begin{tabular}{|c|c|c|c|c|c|}
\hline \multirow{2}{*}{ Treatments } & \multicolumn{4}{|c|}{ Days after infection with $C$. lindemuthianum URM 5771} & \multirow[b]{2}{*}{ CV (\%) } \\
\hline & 4th day & 8th day & 12th day & 20th day & \\
\hline \multicolumn{6}{|c|}{$\beta$-1,3-Glucanase } \\
\hline $\mathrm{BION} \circledast$ & $2.96 \mathrm{Ba}$ & $1.45 \mathrm{Bb}$ & $3.42 \mathrm{Aa}$ & $1.51 \mathrm{Bb}$ & \\
\hline BABA & $3.51 \mathrm{Ba}$ & $0.94 \mathrm{Bb}$ & $2.13 \mathrm{Aa}$ & $2.44 \mathrm{Ba}$ & \\
\hline Chitosan & $1.57 \mathrm{Cb}$ & $2.50 \mathrm{Aa}$ & $3.05 \mathrm{Aa}$ & $3.29 \mathrm{Aa}$ & 27.04 \\
\hline Salicylic acid & $5.94 \mathrm{Aa}$ & $2.75 \mathrm{Ab}$ & $2.48 \mathrm{Ab}$ & $3.67 \mathrm{Ab}$ & \\
\hline T. aureoviride & $2.99 \mathrm{Ba}$ & $1.80 \mathrm{Bb}$ & $2.01 \mathrm{Aa}$ & $2.46 \mathrm{Ba}$ & \\
\hline Control & $4.85 \mathrm{Aa}$ & $2.58 \mathrm{Ab}$ & $2.27 \mathrm{Ab}$ & $1.95 \mathrm{Bb}$ & \\
\hline $\mathrm{CV}(\%)$ & \multicolumn{4}{|c|}{33.13} & \\
\hline \multicolumn{6}{|l|}{ Catalase } \\
\hline $\mathrm{BION} \circledast$ & $16.90 \mathrm{Ab}$ & $26.50 \mathrm{Cb}$ & $67.45 \mathrm{Ca}$ & $4.73 \mathrm{Bc}$ & \\
\hline BABA & $9.70 \mathrm{Ac}$ & $61.39 \mathrm{Ab}$ & $82.81 \mathrm{Ba}$ & $20.47 \mathrm{Ac}$ & \\
\hline Chitosan & $4.18 \mathrm{Ad}$ & $38.75 \mathrm{Bb}$ & $87.36 \mathrm{Ba}$ & $22.49 \mathrm{Ac}$ & 20.48 \\
\hline Salicylic acid & $8.86 \mathrm{Ac}$ & $56.04 \mathrm{Aa}$ & $42.03 \mathrm{Db}$ & $32.39 \mathrm{Ab}$ & \\
\hline T. aureoviride & $11.71 \mathrm{Ac}$ & $47.82 \mathrm{Ab}$ & $135.78 \mathrm{Aa}$ & $7.00 \mathrm{Bc}$ & \\
\hline Control & $10.47 \mathrm{Ac}$ & $40.88 \mathrm{Bb}$ & $69.84 \mathrm{Ca}$ & $15.29 \mathrm{Bc}$ & \\
\hline CV (\%) & \multicolumn{4}{|c|}{30.19} & \\
\hline \multicolumn{6}{|l|}{ Peroxidase } \\
\hline $\mathrm{BION} \circledast$ & $0.10 \mathrm{Ca}$ & $0.12 \mathrm{Aa}$ & $0.04 \mathrm{Aa}$ & $0.03 \mathrm{Aa}$ & \\
\hline BABA & $0.29 \mathrm{Ca}$ & $0.04 \mathrm{Ab}$ & $0.04 \mathrm{Ab}$ & $0.02 \mathrm{Ab}$ & \\
\hline Chitosan & $0.29 \mathrm{Ca}$ & $0.07 \mathrm{Ab}$ & $0.02 \mathrm{Ab}$ & $0.01 \mathrm{Ab}$ & 28.73 \\
\hline Salicylic acid & $0.62 \mathrm{Ba}$ & $0.13 \mathrm{Ab}$ & $0.02 \mathrm{Ab}$ & $0.01 \mathrm{Ab}$ & \\
\hline T. aureoviride & $0.47 \mathrm{Ba}$ & $0.10 \mathrm{Ab}$ & $0.08 \mathrm{Ab}$ & $0.09 \mathrm{Ab}$ & \\
\hline Control & $1.31 \mathrm{Aa}$ & $0.04 \mathrm{Ab}$ & $0.03 \mathrm{Ab}$ & $0.02 \mathrm{Ab}$ & \\
\hline $\mathrm{CV}(\%)$ & \multicolumn{4}{|c|}{30.73} & \\
\hline \multicolumn{6}{|c|}{ Polyphenoloxidase } \\
\hline $\mathrm{BION} \circledast$ & $0.62 \mathrm{Ca}$ & $0.39 \mathrm{Ab}$ & $0.53 \mathrm{Aa}$ & $0.19 \mathrm{Ab}$ & \\
\hline BABA & $0.80 \mathrm{Ba}$ & $0.28 \mathrm{Ab}$ & $0.37 \mathrm{Ab}$ & $0.18 \mathrm{Ab}$ & \\
\hline Chitosan & $0.50 \mathrm{Ba}$ & $0.32 \mathrm{Aa}$ & $0.38 \mathrm{Aa}$ & $0.14 \mathrm{Aa}$ & 32.45 \\
\hline Salicylic acid & $0.83 \mathrm{Ba}$ & $0.32 \mathrm{Ab}$ & $0.25 \mathrm{Ab}$ & $0.10 \mathrm{Ab}$ & \\
\hline T. aureoviride & $1.15 \mathrm{Aa}$ & $0.37 \mathrm{Ab}$ & $0.45 \mathrm{Ab}$ & $0.25 \mathrm{Ab}$ & \\
\hline Control & $0.41 \mathrm{Ba}$ & $0.26 \mathrm{Aa}$ & $0.34 \mathrm{Aa}$ & $0.31 \mathrm{Aa}$ & \\
\hline CV (\%) & \multicolumn{4}{|c|}{34.11} & \\
\hline \multicolumn{6}{|l|}{ Protease } \\
\hline $\mathrm{BION} \circledast$ & $0.66 \mathrm{Ab}$ & $0.46 \mathrm{Bc}$ & $0.52 \mathrm{Bc}$ & $1.02 \mathrm{Aa}$ & \\
\hline BABA & $0.54 \mathrm{Bb}$ & $0.48 \mathrm{Bb}$ & $0.41 \mathrm{Bb}$ & $1.01 \mathrm{Aa}$ & \\
\hline Chitosan & $0.34 \mathrm{Cc}$ & $0.73 \mathrm{Ab}$ & $0.75 \mathrm{Ab}$ & $0.95 \mathrm{Aa}$ & 21.04 \\
\hline Salicylic acid & $0.32 \mathrm{Cd}$ & $0.58 \mathrm{Bb}$ & $0.45 \mathrm{Bc}$ & $0.91 \mathrm{Aa}$ & \\
\hline T. aureoviride & $0.48 \mathrm{Bb}$ & $0.75 \mathrm{Aa}$ & $0.44 \mathrm{Bb}$ & $0.76 \mathrm{Ba}$ & \\
\hline Control & $0.55 \mathrm{Bc}$ & $0.67 \mathrm{Ab}$ & $0.80 \mathrm{Aa}$ & $0.70 \mathrm{Bb}$ & \\
\hline CV (\%) & \multicolumn{4}{|c|}{19.60} & \\
\hline
\end{tabular}

BION®: Acibenzolar-S-methyl; BABA: Amino-butyric acid; CV: Coefficient of variation; Means followed by the same capital letter in the column and lowercase letter in the row do not differ from each other by the Scott-Knott test at a probability of $5 \%$.

The increased antioxidant enzymatic activity of catalase, peroxidase, and polyphenoloxidase contributes to increased plant protection against pathogenic infection, helping to reduce the toxic levels of $\mathrm{H}_{2} \mathrm{O}_{2}$ (Hu et al., 2009). The accumulation of these enzymes depends on the physical conditions of the plant, the phytopathogen, and the resistance inducer (Gayatridevi et al., 2012). 
For protease enzyme production, the highest activity occurred after 20 days of plant pathogen infection in all the evaluated resistance inducers, the treatment with chitosan presented the highest activity on days 8,12 , and 20, and salicylic acid had the lowest activity (Table 3).

The highest activity of protease occurred after 20 days of infection with $C$. lindemuthianum URM 5771, as the antioxidant enzymes reduced their activity (Table 3). Consequently, strong disease severity was observed (Table 2). In microorganisms, protease has been reported to be involved in the process of plant colonization and linked to the induction of secondary metabolites in the protein synthesis related to the role of pathogenesis (Morán-Diez et al., 2009).

We report high correlations between the enzymatic activities of the antioxidant peroxidase and polyphenoloxidase and disease severity for resistance inducers, where salicylic acid presented the highest coefficient of determination $\left(\mathrm{R}^{2}\right)$, thus suggesting this compound as the best for fighting anthracnose infection. The $\beta$-1,3-glucanase enzyme showed the highest $\mathrm{R}^{2}$ in the treatments with chitosan and the control (Figure 2). Even without external agents, the plants expressed relatively high enzymatic activity to fight the phytopathogen.

Understanding plant defense mechanisms enables the development of plant varieties that are more resistant to several types of phytopathogens and pests (Nascimento and Barrigossi, 2014). Treating plants with abiotic and biotic inducers of systemic resistance may increase systemic resistance against pathogens in plants. Importantly, this plant resistance occurs not only locally but also in plant tissues distant from the initial infection, thus promoting physiological changes in the plant biochemistry to stop or reduce the spread and progress of disease (Harman et al., 2012). Thus, more studies are needed to better understand the action of the pathogen in the plant and the reactions of the plant to the phytopathogen under different stress conditions, as well as under field conditions.

The main conclusions are as follows. The abiotic inducers $\mathrm{BION} \AA$, BABA, chitosan, and salicylic acid and abiotic inducer, the fungi T. aureoviride URM5158, present an antagonistic potential to anthracnose caused by C. lindemuthianum URM 5771 in cowpea plants. The spread of anthracnose induced a shift in enzymatic activity. The resistance inducers salicylic acid and T. aureoviride URM 5158 promoted high enzymatic activity in cowpea plants infected with $C$. lindemuthianum URM 5771. We also observed high correlations between the enzymatic activities of peroxidase and polyphenoloxidase and the severity of anthracnose infection in cowpea plants.

\section{Acknowledgements}

The Foundation for Science and Technology Support of the State of Pernambuco (FACEPE), for a master's scholarship, CNPq and Capes, for research funding.

\section{Resumen}

J.M. Silva, M.B.C.L. Medeiros, J.T.C. Oliveira, E.V. Medeiros, C.M. Souza-Motta, y K.A. Moreira. 2018. Inductores de resistencia y mecanismos bioquímicos en el control de la antracnosis en el caupí. Cien. Inv. Agr. 45(3): 290-300. Se observan diferentes respuestas en la planta después de la infección por patógenos. El uso de inductores sistémicos ya sean bióticos o abióticos tiene la función de aumentar la producción enzimática del sistema de defensa de la planta. En ese sentido, nuestra presente investigación tiene como objetivo evaluar la severidad de la enfermedad en plantas de caupí cultivares "sempre-verde" infectadas con Colletotrichum lindemuthianum URM 5771, el agente de la antracnosis, y sometidas a inductores de resistencia tanto bióticos como abióticos, así como estimular la enzimática actividad de defensa de planta. 
Figure 2. Correlation between the enzymatic activity $\left(\mathrm{U} \mathrm{min}^{-1} \mathrm{mg}^{-1}\right)$ and the disease severity of anthracnose after infection with Colletotrichum lindemuthianum URM 5771 in the cowpea cultivar "sempre-verde" (Vigna unguiculata (L.) Walp.) subjected to different abiotic plant resistance inducers and the Trichoderma aureoviride URM 5158 as the biotic plant resistance inducer. BION®: Acibenzolar-S-methyl; BABA: Amino-butyric acid.
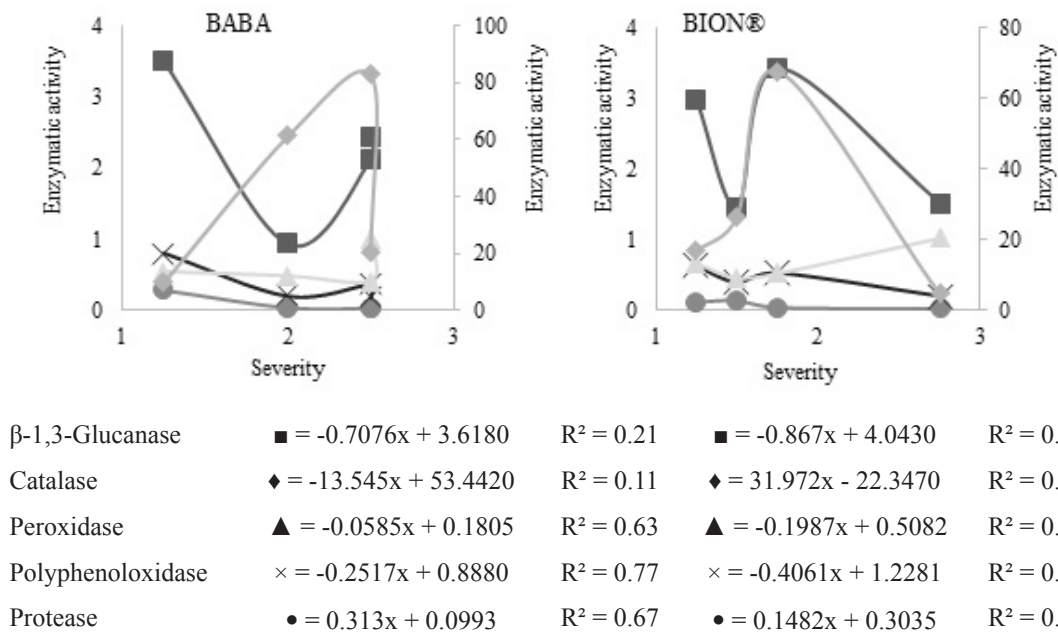

$$
\begin{array}{lll}
\mathrm{R}^{2}=0.21 & \text { }=-0.867 \mathrm{x}+4.0430 & \mathrm{R}^{2}=0.23 \\
\mathrm{R}^{2}=0.11 & \bullet=31.972 \mathrm{x}-22.3470 & \mathrm{R}^{2}=0.30 \\
\mathrm{R}^{2}=0.63 & \boldsymbol{\Delta}=-0.1987 \mathrm{x}+0.5082 & \mathrm{R}^{2}=0.87 \\
\mathrm{R}^{2}=0.77 & \times=-0.4061 \mathrm{x}+1.2281 & \mathrm{R}^{2}=0.69 \\
\mathrm{R}^{2}=0.67 & \bullet=0.1482 \mathrm{x}+0.3035 & \mathrm{R}^{2}=0.10
\end{array}
$$

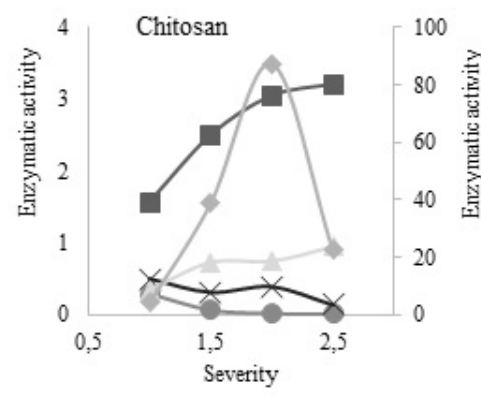

$$
\begin{array}{ll}
\beta-1,3-\text { Glucanase } & \boldsymbol{\bullet}=1.092 \mathrm{x}+0.6710 \\
\text { Catalase } & \bullet=20.71 \mathrm{x}+1.9525 \\
\text { Peroxidase } & \boldsymbol{\Delta}=0.3686 \mathrm{x}+0.0502 \\
\text { Polyphenoloxidase } & \times=-0.1998 \mathrm{x}+0.6884 \\
\text { Protease } & \bullet=-0.1758 \mathrm{x}+0.4054
\end{array}
$$
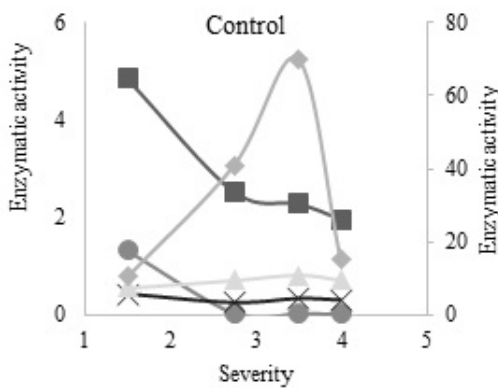

$$
\begin{array}{lll}
\mathrm{R}^{2}=0.91 & \boldsymbol{\bullet}=-2.5451 \mathrm{x}+9.1188 & \mathrm{R}^{2}=0.60 \\
\mathrm{R}^{2}=0.14 & \boldsymbol{\bullet}=22.351 \mathrm{x}-12.6640 & \mathrm{R}^{2}=0.29 \\
\mathrm{R}^{2}=0.87 & \boldsymbol{\Delta}=-0.5765 \mathrm{x}+1.4199 & \mathrm{R}^{2}=0.89 \\
\mathrm{R}^{2}=0.73 & \times=-0.6282 \mathrm{x}+1.7066 & \mathrm{R}^{2}=0.89 \\
\mathrm{R}^{2}=0.76 & \bullet=0.3447 \mathrm{x}-0.1675 & \mathrm{R}^{2}=0.42
\end{array}
$$
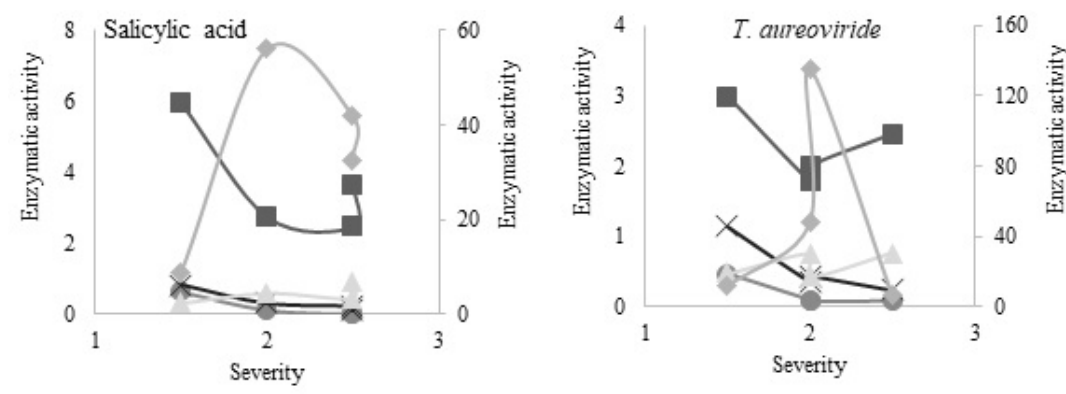

$$
\begin{array}{ll}
\beta-1,3 \text {-Glucanase } & \boldsymbol{\bullet}=-0.529 \mathrm{x}+3.3735 \\
\text { Catalase } & \bullet=-4.71 \mathrm{x}+59.9960 \\
\text { Peroxidase } & \boldsymbol{\Delta}=-0.38 \mathrm{x}+0.9475 \\
\text { Polyphenoloxidase } & \mathrm{x}=-0.902 \mathrm{x}+2.3555 \\
\text { Protease } & \bullet=0.278 \mathrm{x}+0.0505
\end{array}
$$

$\mathrm{R}^{2}=0.17$

- $=-1.1536 x+6.2876$

$\mathrm{R}^{2}=0.90$

$\mathrm{R}^{2}=0.01$

$\downarrow=9.2531 \mathrm{x}+6.9369$

$\mathrm{R}^{2}=0.13$

$\mathrm{R}^{2}=0.67$

$\boldsymbol{\Delta}=-0.5236 \mathrm{x}+1.8890$

$\mathrm{R}^{2}=0.78$

$\mathrm{R}^{2}=0.82$

$x=-0.0362 x+0.4368$

$\mathrm{R}^{2}=0.39$

$\mathrm{R}^{2}=0.44$

$\mathrm{R}^{2}=0.66$ 


\begin{abstract}
El experimento se realizó en invernadero con un diseño de parcelas divididas completamente aleatorizado en el tiempo, con seis tratamientos: cuatro inductores de resistencia de plantas abióticas acibenzolar-S-metilo, ácido $\beta$-aminobutírico, quitosano y ácido salicílico, un inductor biótico, los hongos filamentosos Trichoderma aureoviride URM 5158, y un control con solo agua. Las hojas de la planta se muestrearon en cuatro puntos de tiempo, 4, 8, 12 y 20 días después de la inoculación del patógeno de la planta, para medir la actividad enzimática de la $\beta$-1,3-glucanasa, la catalasa, la peroxidasa, la polifenoloxidasa y la proteasa. Los inductores abióticos acibenzolar-S-metil, $\beta$-aminobutírico, quitosano y el inductor biótico presentaron el mayor potencial para reducir la antracnosis causada por C. lindemuthianum URM 5771 en las plantas de caupí al mostrar los valores más bajos en la escala de severidad de las lesiones a lo largo del tiempo. La progresión de la enfermedad proporcionó un cambio en la actividad enzimática donde los inductores de ácido salicílico y T. aureoviride URM 5158 promovieron la actividad enzimática más alta en comparación con los otros inductores. Se observaron altas correlaciones entre la actividad enzimática de la peroxidasa y la polifenoloxidasa y la severidad de la antracnosis en las plantas de caupí. El uso de inductores de resistencia abióticos y bióticos presenta un alto potencial para la lucha contra la antracnosis en las plantas de caupí, sin embargo, se deben realizar más estudios que cubran diferentes ambientes, variedades de plantas y condiciones climáticas.
\end{abstract}

Palabras claves: Enfermedad del frijol, inductores abióticos, inductores bióticos, Vigna unguiculata (L.) Walp.

\section{References}

Alencar, R.B., M.M. Biondi, P.M.G. Paiva, V.L.A. Vieira, L.B. Carvalho Junior, and R.S. Bezerra. 2003. Alkaline proteases from digestive tract of four tropical fishes. Brazilian Journal Food Technologgy, 6:279-284.

Andrade, C.C.L., R.S. Resende, F.A. Rodrigues, P.R. Silveira, J.A. Rios, J.R. Oliveira, and R.L.R. Mariano. 2013. Indutores de resistência no controle da pinta bacteriana do tomateiro e na atividade de enzimas de defesa. Tropical Plant Pathology, v.38:28-34.

Companhia Nacional de Abastecimento - CONAB. 2017. Acompanhamento da safra brasileira de grãos, 2 V. 4-SAFRA 2016/17-N.

Bol, J.F., H.J.M. Linthrost, and B.J.C. Cornelissen. 1990. Proteínas relacionadas com a patogênese das plantas induzidas por infecção por vírus. Annual Review Phytopathology, 28:113-138.

Davar, R., R. Darvishzadeh, and A. Majd. 2013. Changes in antioxidant systems in sunflower partial resistant and susceptible lines as affected by Sclerotinia sclerotiorum. Biologia, 68:821-829.

Food and Agriculture of United Nations - FAO.
2013. Base de dados. Available in: $<$ http://faotat. fao.org/faostat/>. Acesso in: October, 20, 2017.

Gayatridevi, S., S.K. Jayalakshimi, and K. Sreeramulu. 2012. Saliccylic acid is a modulator of catalase isozymes in chickpea plants infected with Fusarium oxysporum f. sp. ciceri. Plant Physiology and Biochemistry, 52:154-161.

Harman, G.E., A.H. Herrera-Estrella, B.A. Horwitz, and M. Lorito. 2012. Special issue: Trichoderma - from basic biology to biotechnology. Microbiology, 158:1-2.

Havir, E.A., and N.A. Mchale. 1987. Biochemical and development characterization of multiple forms of catalase in tobacco leaves. Plant Physiologic, 84:450-455.

Hu, Z.H., Y.B. Shen, F.Y. Shen, and X.H. Su. 2009. Effects of feeding Clostera anachoreta on hydrogen peroxide accumulation and activities of peroxidade, catalase, and ascorbate peroxidase in Populus simonii x P. pyramidalis 'Opera 8277' leaves. Acta Physiologiae Plantarum, 1:9951002.

Kar, M., and D. Mishra. 1976. Catalase, peroxidase, and polyphenoloxidase activities during rice leaf senescence. Plant Physiology, 57:315-319. 
Köppen, W., and Geiger, R. 1928. Klimate der Erde, Verlag Justus Perthes, Gotha, Wall-Map.

Leal, I.G., A.M.A. Accioly, C.W.A. Nascimento, M.B.G.S. Freire, A.A.A. Montenegro, and F.L. Ferreira. 2008. Fitorremediação de solo salino sódico por Atriplex nummularia e gesso de jazida. Revista Brasileira de Ciência do Solo, 32:1065-1072.

Lever, M.A. 1972. New reaction for colorimetric determination of carbohydrates. Analytical Biochemistry, 47:273-279.

Mittler, R. 2002. Oxidative stress, antioxidants and stress tolerance. Trends in Plant Science, 7:405410.

Mohanapriya, R., R.Naveenkumar, and P. Balabaskar. 2017. Survey, virulence and pathogenicity of root rot incidence of cowpea in selected districts of Tamilnadu caused by Macrophomina phaseolina (Tassi.) Goid. Internacional Journal of Current Microbiology and Applied Science, 6:694-705.

Morán-Diez, E., R. Hermosa, P. Ambrosino, R.E. Cardoza, S. Gutiérrez, H. Lorito, and E. Monte. 2009. The ThPG1 endopolygalacturonase is required for the Trichoderma harzianum-plant beneficial interaction. Molecular Plant-Microbe Interactions, 22:1021-1031.

Nascimento, J.B., and J.A.F. Barrigossi. 2014. O papel das enzimas antioxidantes na defesa das plantas contra insetos herbívoros e fitopatógenos. Agrarian Academy, 1:234-250.

Pradhan, D., D.Mathew, S.K.Mathew, and P.A. Nazeem. 2017. Identifying the markers and tagging a leucine-rich repeat receptor-like kinase gene for resistance to anthracnose disease in vegetable cowpea [Vigna unguiculata (L.) Walp.]. The Journal of Horticultural Science and Biotechnology, 1:1-8.

Ramírez, J.G., A.B. Jaraba, and P.E Buriticá. 2014. Manejo de la pudrición acuosa del pseudo-tallo
(Dickeya sp.) em banano (Musa sp.) bajo condiciones de invernadeiro. Agronomía Costarricense, 38:83-92.

Rava, C.A., J. Molina, N. Kauffmann, and I. Brions. 1993. Determinación de razas fisiológicas de Colletotrichum lindemuthianum en Nicaragua. Tropical Plant Pathology, 18:388-391.

Santos, L.A.C., D.M.P. Silva, I.A. Oliveira, C.E. Pereira, and M.C.C. Campos. 2017. Crescimento de cultivares de feijão-caupi em solo de terra firme e várzea. Ambiência Guarapuava, 13:261-270.

Silva, E.P., V.F.F. Gomes, P.F. Mendes Filho, J.M.T. Silva Júnior, and R.L.L. Ness. 2016b. Desenvolvimento e colonização micorrízica em mudas de embaúba adubadas com fosfato natural e material orgânico. Revista Ciência Agronômica, 47:256-263.

Silva, J.A.T., E.V. Medeiros, J.M. Silva, D.A. Tenório, K.A. Moreira, T.C.E.S. Nascimento and C. Souza-Motta. 2017. Antagonistic activity of Trichoderma spp. against Scytalidium lignicola CMM 1098 and antioxidant enzymatic activity in cassava. Phytoparasitica 45:219-225.

Silva, J.A.T., E.V. Medeiros, J.M. Silva, D.D.A. Tenório, K.A. Moreira, T.C.E.D.S. Nascimento, and C. Souza-Motta. 2016a. Trichoderma aureoviride URM 5158 and Trichoderma hamatum URM 6656 are biocontrol agents that act against cassava root rot through different mechanisms. Journal of Phytopathology, 164:1003-1011.

Singh, B.N., A. Singh, S.P. Singh, and H.B. Singh. 2011. Trichoderma harzianum - mediated reprogramming of oxidative stress response in root apoplast of sunflower enhances defense against Rhizoctonia solani. European Journal of Plant Pathology, 131:121-134.

Urbanek, H., E. Kuzniak-Gebarowska, and K. Herka. 1991. Elicitation of defense responses in bean leaves by Botrytis cinerea polygalacturonase. Acta Physiologiae Plantarum, 13:43-50. 